\title{
The Potential of Rambutan Seed Extract to Reduce Risk of Cardiovascular Disease in Diabetes Mellitus Type 2
}

\author{
Retno Susilowati \\ Maulana Malik Ibrahim State Islamic University of \\ Malang, Indonesia \\ retnosusilowatibms@gmail.com \\ Leni Susilo Andriani N \\ Maulana Malik Ibrahim State Islamic University of \\ Malang, Indonesia
}

\author{
Malinda Farikatul Ibrizah \\ Maulana Malik Ibrahim State Islamic University of \\ Malang, Indonesia \\ Khairun Nisa \\ Maulana Malik Ibrahim State Islamic University of \\ Malang, Indonesia
}

\begin{abstract}
This study aimed to find out the potential of ethanol extract in rambutan seed to reduce the risk factors of cardiovascular disease by using animal model on diabetes-type 2 (DM-2). The animals used for this study were 3-4 months old male wistar mice with 20-25 grams weight. The diabetes mellitus induction type 2 to the animal model was performed through the administration of high fat diet for 4 weeks followed by the daily dosage of Streptozotocin (STZ) $40 \mathrm{mg} / \mathrm{kgbw}$ and it was repeated for 4 times in the last week of induction. The administration of $70 \%$ ethanol extract of Binjai rambutan seed (Naphelium lappaceum L.) was done in Carboxy Methyl Cellulose $0.5 \%$ and metformin as positive control. The result indicated that $70 \%$ ethanol extract of Binjai rambutan seeds had a significant effect on the atherosclerosis index $(p<0,01)$ and all lipid profile parameters. The Binjai rambutan seed extract at $\mathbf{1 9 . 2}$ $\mathrm{mg} / \mathrm{kgbw}$ dose was the most effective to decrease the atherosclerosis index, total cholesterol, triglyceride, low density lipoprotein, and malodialdehyde and to increase high density lipoprotein and super oxide dismutase of mice blood serum. It can be concluded that the rambutan seed extract at the dose of $\mathbf{1 9 . 2}$ $\mathrm{mg} / \mathrm{kgbw}$ had the potential to reduce the risk of cardiovascular diabetes in mice by increasing lipid fraction and decreasing oxidative stress.
\end{abstract}

Keywords: atherosclerotic index, binjai rambutan seed (Naphelium lappecium L.), diabetes mellitus, lipid profile

\section{INTRODUCTION}

Many cases of cardiovascular diseases in most developing countries including Indonesia cause morbidity and mortality and it requires substantial amount of treatment. Cardiovascular disease is nonCommunicable Diseases (NCDs) that causes the main death in South East Asia. NCDs data profile in 2014 showed that $71 \%$ of $1,551,000$ deaths in Indonesia were attributed to NCDs. Cardiovascular Disease (CVDs) was the biggest leading cause of death among 4 major NCDs with $37 \%$ of deaths followed by cancer (13\%), DM $(10 \%)$ and Chronic Respiratory Disease (CRD) was by $5 \%$ [1]. Chronic DM is also a source of various risk factors causing CVDs either traditinal or non-traditional risk factors such as hypecholesterolemia, hypertension, insulin resistance and hyperglycemia.

The DM-2 patient prevalence dominates the cases of DM, approximately $80 \%$ of the DM cases. DM-2 is a disease caused by metabolic disorders which are characterized by symptoms of hyperglycemia because of the insulin resistance. Glucose limitation in the cells caused by the insulin resistance and leads to a disturbance on the lipid metabolic balance in most of human body tissue. Insulin resistance in fatty tissues obstructs lipogenesis and increases lipolysis. This will trigger glucotoxicity followed by lipotoxicity and leads to the increase of risk factors for cardiovascular disease, for example the increase of total cholesterol (TC), triglyceride (TG), and low density lipoprotein (LDL) levels and the decrease of high density lipoprotein (HDL) levels. Despite as a source of dyslipidemia, the increase of blood sugar levels can trigger oxidative stress and lead to the production of Reactive Oxygen Species (ROS) through the glucose autooxidation pathway. Atherosclerosis is as a cause of various cardiovascular diseases, it is resulted from chronic inflammatory reactions that involves Low Density Lipoproteine (LDL) and it is oxidized to foam cell macrophages in the sub endothelial vessel layer. Therefore, chronic DM patients have the potential to increase the LDL oxidation rate, thus having more risks of atherosclerosis and CVD compared to those with ordinary risk factors [2].

Phenolic of Rambutan seed methanol extract is 124 mg GAE/g DW (Garlic Acid Equivalent, GAE; Dried Weight, DW) and DPPH scavenging activity is $383 \mathrm{mg}$ VCEAC/g DW (Vitamin C Equivalent Antioxidant Capacity, VCEAC) [3]. It was also reported that 
rambutan seed extract from the cultivar Sichompu of rambutan inhibited ROS formation [4]. Dry rambutan seed contains of a phytochemical with antioxidant characteristic (in $\mathrm{mg} / 100 \mathrm{~g}$ ) such as saponin $(2.10 \pm 0.05$ ), alkaloid (1.95 \pm 0.02$), \quad \mathrm{HCN} \quad(0.00 \pm 0.00)$, tannin $(0.28 \pm 0.01)$, phytate $(0.77 \pm 0.03)$, phenol $(0.41 \pm 0.09)$, oxalate $(0.19 \pm 0.01)$, and flavonoids $(1.63 \pm 0.32)[5]$, there are pretty much alkaloid in the rambutan seed extract. A previous study on the alkaloid test could inhibit 3T3 the preadipocyte differentiation. It was also reported that in vivo test in mice with HFD showed that the component could inhibit adiposity, obesity and body fat accumulation, which was characterized by the decreased levels of TC, TG, and LDL and the increase of HDL [6].

Atherogenic index (AI) of Plasma is LDLc/HDLc that can be used as a regular monitoring index of CVD in every day practice, especially for people with cardiovascular risk factors [7]. Based on the previous studies, it is predicted that $70 \%$ of ethanol extract in rambutan seed is anti hyperlipidemic and rich of antioxidant. Thus, this study aimed to determine the potential of ethanol extract in rambutan seed for decreasing the atherogenic index in mice with DM-2. The supporting parameters in this study included the decrease of lipid serum profile including LDL and HDL levels, oxidative stress levels including SOD and MDA.

\section{METHOD}

\section{Research Design}

This study employed Completely Randomized Design with 6 treatments and 4 repetitions. It used 24 mice (Mus musculus L.) Strain Balb-C, they were 2-3 months old and their weight were 20-30 g , around 20 mice were induced with DM-2. The mice with DM-2 were divided into 5 groups. For the positive control, they were given metformin dose $39 \mathrm{mg} / \mathrm{kgbw}$ (DMmet), and for the negative control without treatment (DMd0). One group was given rambutan seed extract at a dose of 19.2 $\mathrm{mg} / \mathrm{kgbw}$ (DMd19) while another group was given rambutan seed extract at a dose of $23,4 \mathrm{mg} / \mathrm{kgbw}$ (DMd23). It was repeated until 4 times for each group. Meanwhile, a group of 4 mice was normal nonDM (nDM). The $\mathrm{nDM}$ and $\mathrm{DMd} 0$ groups were given $0.5 \%$ CMC as placebo. The treatments of ethanol extract in rambutan seed, metformin and $\mathrm{CMC}$ were given orally at a dosage of $0.5 \mathrm{ml}$ for 30 days.

\section{Herbal Extraction, animal model induction and blood serum preparation}

Rambutan seed extraction was done by using a maceration method with $70 \%$ ethanol solvent referred to Vongsak et al. [8]. The induction of DM-2 to the animal model was performed by giving the High Fat Diet (HFD) followed by the injection of STZ in multiple low dosages referred to Zang et al., [9]. The Streptozotocin used was Bio-world, USACat 714992 CAS 18883-66-4.
Blood was taken from the heart of the fasting mice to which dislocation of the neck was previously performed. Blood was centrifuged at $3000 \mathrm{rpm}$ for 15 minutes to obtain a clear supernatant. The measurements of SOD and MDA were performed immediately on fresh serum, while the remaining serum was stored at $-80^{\circ} \mathrm{C}$ for the measurement of lipoprotein level.

\section{Techniques of Measurement}

FBG level was measured by using Accutrend Plus Cholesterol Meter from Roche. The cLDL Reagent precipipation measurement to determine the cLDL level was performed using CHOD-PAP method on photometric systems, DiaSys, Germany. Meanwhile, the HDLc measurement was performed using Differential Precipitation Enzymatic Cororymetric Test Endpoint from Glory Diagnostic, with Reagent from Glory Diagnostic, Spanyol, GD-HDLP80 and GDHDLP180.Measurement of serum cHDL level by using Differential Precipitation Enzymatic Colorymetric Test Endpoint method.

SOD activity was determined spectrophotometrically by using Superoxide Dismutase (SOD) Assay Kit Catalogue No: E-BC-K020. SOD activity was measured by the WST-1 method, the measurement procedure followed by the protocol attached to the kit and the measurement used a spectrofotometer at $\lambda 450 \mathrm{~nm}$. The level of MDA was measured by TBARS method. TBA from Sigma Aldrich. Spectrophotometric determination of MDA-TBA withUV-Vis spectrophotometer at $\lambda 533$ $\mathrm{nm}$ at room temperature, the principal measurement refers to Setin et al.[10]. AI was calculated by dividing LDLc with HDLc level.

\section{Data Analysis}

Data of the effect of $70 \%$ of ethanol extract in rambutan seed on the levels of LDLc, HDLc, MDA, SOD dan AI which met the parameter data rules (being distributed and having homogen variance values) were analyzed using One Way Anova test, to find out the significant mean. When the result was significant, further test of Duncant Multiple Range Test (DMRT) was performed with $\mathrm{p}=0,05$. If the data did not meet the parameter rules, Mann-Whiteney U-Test was performed. The statistic test was done using SPSS program ver.16.0

\section{RESULT}

HFD diet and STZ injection succeeded in increasing the blood sugar as well, FBG level was increased from $101.75 \pm 31.521 \mathrm{mg} / \mathrm{dL}$ in normal mice to $420.19 \pm 20.347 \mathrm{mg} / \mathrm{dL}$ in mice with DM. The mean of DM-2 FBG level were at least $285 \mathrm{mg} / \mathrm{dl}$ (complete data not shown). Statistic result of LDL and HDL serum level shown at figure 1, SOD and MDA level at figure 2, and AI at figure 3 . 
A

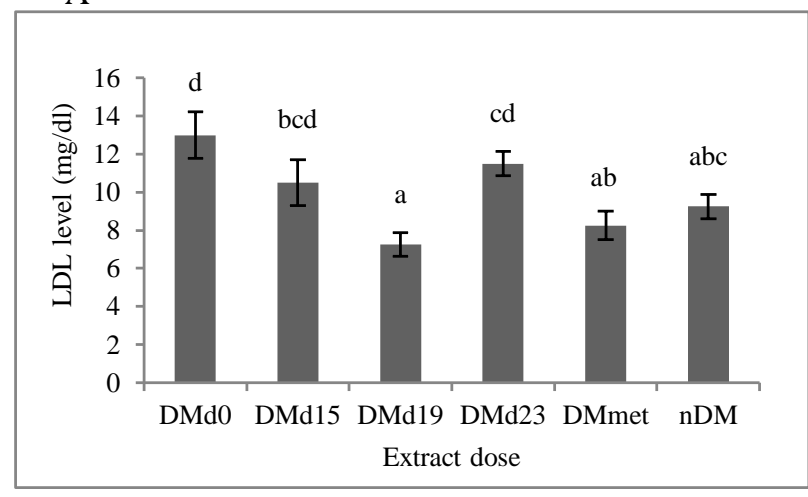

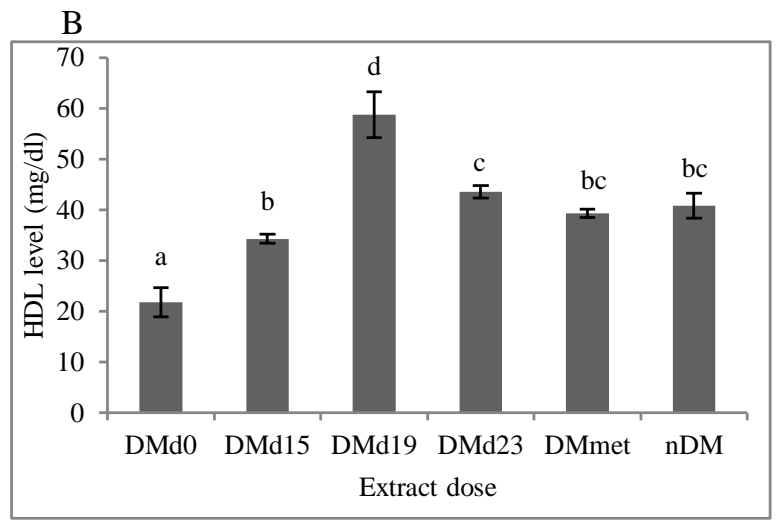

Figure 1: The Effect of Rambutan Seed Extract on Characteristic Mice Serum A. LDL B. HDL Note: Different label is significant in DMR t test $\dot{\alpha}=5 \%$.

A

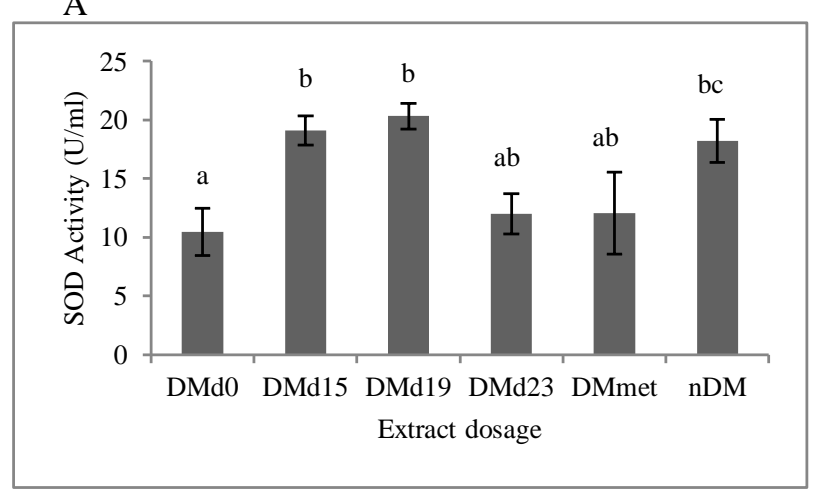

B

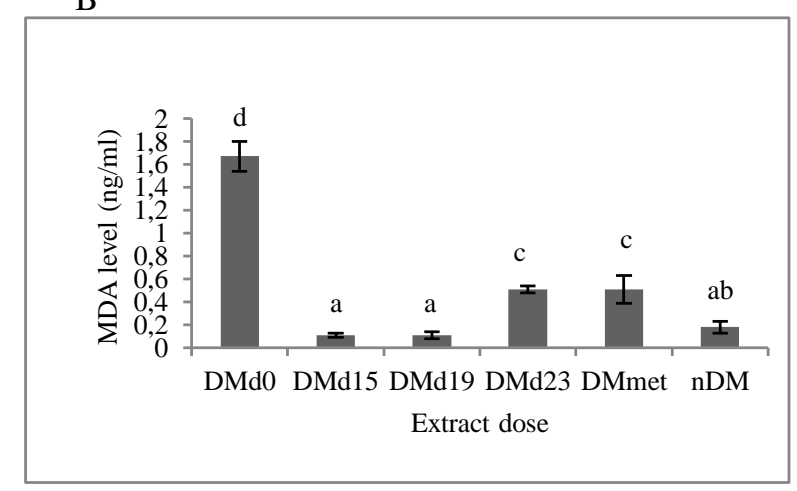

Figure 2: The Effect of Rambutan Seed Extract on the Characteristic Mice Serum A. SOD B. MDA Note: Different label is significant in SOD DMRT test 5\% and MDA U-Mann Whiteney test $\alpha=5 \%$.

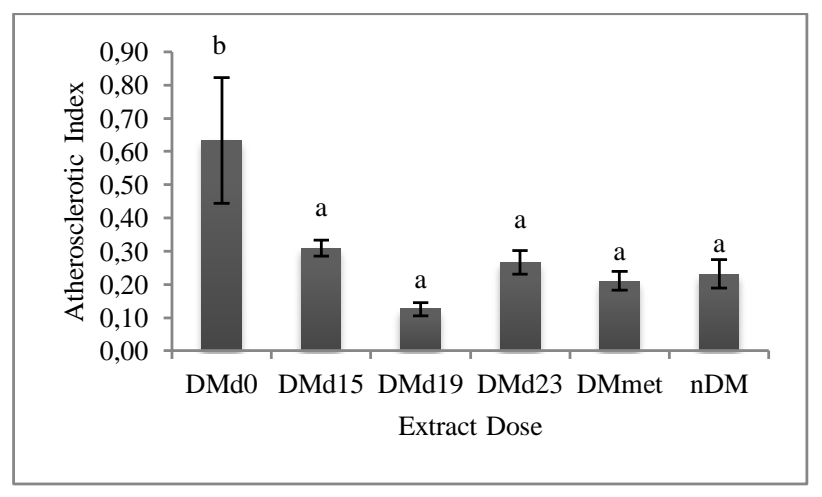
Index

Figure 3. The Effect of Rambutan Seed Extract on Atherosclerotic

Note: Different label is significant in AI DMRT test $\alpha=5 \%$.

\section{DISCUSSION}

The FBG of mice that received HFD and STZ injection in this research was increasing the blood sugar level up to $55 \%$ in diabetic category, $\mathrm{FBG} \geq 285 \mathrm{mg} / \mathrm{dl}$. This is in line with the required mice with DM by Alacron-Aguilar at FBG> 200mg/kgbw[11]. The level of
FBG in mice with DM and administered with rambutan seed extract decreased significantly. The results of this study support the results of Soeng in 2015 in which the rambutan seed extract of $70 \%$ ethanol on pre-adipocyte 3T3 cell culture is able to decrease $\alpha$-glucosidase activity, thereby decreasing the blood glucose level. In addition, Soeng et al. also reported an anti-obesity effect of rambutan seed extract by decreasing G6PDH activity and TG levels. Moreover, $70 \%$ ethanol extract of rambutan seed is able to give much better effect than hexane fraction at the same concentration [12].

The animal model of DMd0 showed high glucose levels, experiencing hyperlipidemia, increased MDA and decreased SOD. These data are consistent with the patient serum profile, the DM patients experienced hyperlipidemia and decreased SOD compared to normal individuals [13] and DM patients with high HBA1c (glycated hemoglobin) showed increasing MDA and decreasing SOD [14]. In DM-2 patients, the lipid profile significant increases except HDL cholesterol. It tends to decrease. Similarly, there is a significant decrease in antioxidant enzymes such as reduced glutathione, glutathione peroxides, glutathione reductase, and superoxide dismutase, except catalase as compared to the control subjects. Other findings showed that the level of 
lipid peroxide (MDA) increased as per the increase in the blood glucose concentration [15].

The high ratio of LDL/HDL is associated with the risk of atherosclerosis. The higher the ratio, the higher the risk of atherosclerosis, which then known as the Atherosclerosis Index (AI). In this study, the administration of rambutan seed extract significantly decreases AI compared to DM mice. The value is similar with in mice receiving standard drug and normal mice. Hyperlipidemia accompanied by oxidative stress potentially triggers lipid peroxidation and endothelial dysfunction. Low Density Lipoprotein Cholesterol (LDLc) is a material which turns into non-self material if oxidized thus stimulating the inflammatory reaction and chronically having been able to develop into atherosclerosis [16].

\section{CONCLUSION}

Based on the result, it is concluded that administration of $70 \%$ alcohol extract of rambutan seed potentially lowers the risk of CVD in the DM patients because it decreases not only the level of blood glucose as the main factor, but also other proatherogenic conditions such as lowering the levels of LDL atheroma materials and improving oxidative stress by increasing the SOD enzymatic antioxidant.

\section{ACKNOWLEDGMENT}

We would like to thank Romaidi for his technical assistance on this manuscript.

\section{REFERENCES}

[1] A. D.-G. Alwan Ala, "Noncommunicable Diseases and Mental Health, Global status report on noncommunicable diseases 2010," in World Health Organization, 2011.

[2] Y. M. Smulders, J. S. Burgers, T. Scheltens, B. A. Van Hout, T. Wiersma, and M. L. Simoons, "Clinical practice guideline for cardiovascular risk management in the Netherlands," Neth. J. Med., vol. 66, no. 4, pp. 169-174, 2008.

[3] W. Chunglok, T. Utaipan, N. Somchit, M. Lertcanawanichakul, and Y. Sudjaroen, "Antioxidant and antiproliferative activities of non-edible parts of selected tropical fruits," Sains Malaysiana, vol. 43, no. 5, pp. 689-696, 2014.

[4] W. O. Fila et al., "Comparative anti-nutrients assessment of pulp, seed and rind of rambutan (Nephelium lappaceum)," Ann. Biol. Res., vol. 3, no. 11, pp. 5151-5156, 2012.

[5] P. Chingsuwanrote, C. Muangnoi, K. Parengam, and S. Tuntipopipat, "Antioxidant and antiinflammatory activities of durian and rambutan pulp extract," Int. Food Res. J., vol. 23, no. 3, pp. 939-947, 2016.

[6] X. Bin, W. Jin, W. Wenqing, S. Chunyang, H. Xiaolong, and F. Jianguo, "Nelumbo nucifera alkaloid inhibits 3T3-L1 preadipocyte differentiation and improves high-fat diet-induced obesity and body fat accumulation in rats," $J$. Med. Plants Res., vol. 5, no. 10, pp. 2021-2028, 2011.

[7] S. Niroumand et al., "Atherogenic Index of Plasma (AIP): A marker of cardiovascular disease," Med. J. Islam. Repub. Iran, vol. 29, no. 1, pp. 627-635, 2015

[8] M. Zhang, X.-Y. Lv, J. Li, Z.-G. Xu, and L. Chen, "The Characterization of High-Fat Diet and Multiple Low-Dose Streptozotocin Induced Type 2 Diabetes Rat Model," Exp. Diabetes Res., vol. 2008, pp. 1-9, 2008.

[9] B. Vongsak, P. Sithisarn, S. Mangmool, S. Thongpraditchote, Y. Wongkrajang, and W. Gritsanapan, "Maximizing total phenolics, total flavonoids contents and antioxidant activity of Moringa oleifera leaf extract by the appropriate extraction method," Ind. Crops Prod., vol. 44, no. January 2013, pp. 566-571, 2013.

[10] R. Setin and C. Mahdi, "Study on iNOS Expression and Levels of Malondialdehyde ( MDA ) in the White Rat ( Rattus norvegicus ) Exposed with Aggregatibacter actinomycetemcomitans ( Aa )," vol. 2, no. August, pp. 55-61, 2013.

[11] F. J. Alarcon-Aguilar, R. Roman-Ramos, J. L. Flores-Saenz, and F. Aguirre-Garcia, "Investigation on the hypoglycaemic effects of extracts of four Mexican medicinal plants in normal and alloxan-diabetic mice," Phyther. Res., vol. 16, no. 4, pp. 383-386, 2002.

[12] S. Soeng, E. Evacuasiany, W. Widowati, N. Fauziah, V. T. Manik, and M. Maesaroh, "Inhibitory potential of rambutan seeds extract and fractions on adipogenesis in 3T3-L1 cell line," J. Exp. Integr. Med., vol. 5, no. 1, pp. 5560, 2015.

[13] S. Ali Umar, "The Potential Roles of Superoxide Dismutase, Matrix-Metalloprotinase-9 and Interlukine -18 with the Prevalence and Progression of Type II Diabetes Mellitus," Am. J. Intern. Med., vol. 3, no. 3, p. 103, 2015.

[14] N. I. A. Haddad, E. Nori, and S. H. Ali, "The Effect of Type Two Diabetes Mellitus on Superoxide Dismutase ( SOD ) Activity and its Correlation with HbA1c in Iraqi Patients," no. 4, pp. 7-15, 2016.

[15] M. Kumawat, I. Singh, N. Singh, and S. Kharb, "Lipid Peroxidation and Lipid Profile in Type II Diabetes Mellitus," Webmedcentral, vol. 3, no. 3, pp. 1-9, 2012.

[16] R. Susilowati, D. Sargowo, R. Indra, A. Tjokroprawiro, and S. Widyarti, "Correlation Between The Level of Lp-PLA2, MDA, F2- Isp in Serum And Aortic Tissue With The Number of Foam Cells at Atherogenesis Process in Wistar Rats," J. Kardiol. Indones., vol. 33, no. LpPLA2, pp. 227-235, 2012. 